Tropical Bryology 9: 43-57, 1994

\title{
On the bryogeography of Western Melanesian Lejeuneaceae, with comments on their epiphyllous occurrence
}

Sinikka Piippo

Botanical Museum, P.O. Box 47, FIN-00014 University of Helsinki, Finland

\begin{abstract}
The phytogeography of Western Melanesian (Papua New Guinea, West Irian and the Solomon Islands) Lejeuneaceae was studied on the basis of previous literature and the Huon Peninsula material from the Koponen-Norris expedition. The largest portion of the Lejeuneaceae belong to Western Melanesian and Malaysian endemics. The number of Western Melanesian endemic Lejeuneaceae $(20.5 \%)$ is, however, somewhat lower than generally in hepatics $(38.2 \%)$. This is apparently due to the large number of epiphyllous taxa in the Lejeuneaceae, a group especially widespread in lowland rainforests.
\end{abstract}

\section{Introduction and material and methods}

According to the present knowledge, Western Melanesia has a greater diversity of Lejeuneaceae than any other place in the world (Table 1). Only in Borneo is there a comparably rich flora. The number of Lejeuneaceae reported from Western Melanesia increased from 197 to 235 between 1983 and 1993 (Piippo 1994a). Eleven doubtful species, however, have been omitted from the present phytogeographical study (see Results).
This paper is based on previous literature: Bischler (1968), Bischler \& Piippo (1991), Bonner (1963, 1978), Gradstein (1975, 1985, 1991), Gradstein \& Buskes (1985), Gradstein \& Terken (1981), Grolle (1966, 1967, 1968, 1982, 1985, 1986, 1987, 1988), Grolle \& Piippo (1984, 1990), Jovet-Ast (1953, 1960, 1961), Long \& Grolle (1990), Luo (1990), Menzel (1988), Miller et al. (1983), Mizutani (1963, 1964, 1965, 1967, 1968, 1970, 1972a, 1972b, 1973, 1975, 1976, 1977, 1978, 1979a, 1979b, 1980, 1981, 1982, 1984a, 1984b, 1984c, 1985, 1986a, 
1986b, 1987, 1988, 1989, 1990), Mizutani \& Piippo (1986), Onraedt (1991), Piippo (1986, 1990), Pócs (1984), Pócs et al. (1994), Scott \& Bradshaw (1986), Tan \& Engel (1986), Thiers (1987, 1988a, 1992), Thiers \& Gradstein (1989), and Tixier (1980, 1985, 1988). Phytogeographical units are according to Hyvönen (1989) and Enroth (1991). Previous phytogeographical studies (Piippo et al. 1987, Enroth 1991, and Piippo 1992a, 1994b) have spoken of "endemics of New Guinea". In this paper, I broaden the coverage and speak of "endemics of Western Melanesia" to include also hepatics of the Solomon Islands.

The other part of this paper deals with epiphyllous taxa of Lejeuneaceae and especially their altitudinal ranges. This part is based totally on the Huon Peninsula material determined by $\mathrm{M}$. Mizutani and T. Pócs. The material for the epiphyllous study is obtained from the collections of the Koponen-Norris expedition (Koponen \& Norris 1983) in 1981 to the Huon Peninsula, Papua New Guinea. The methods of the expedition and details of the study area are presented by Koponen \& Norris (1983).

The results of the Huon project are being published in Annales Botanici Fennici and Acta Botanica Fennica, with 55 papers now having been published or in press (the latest, on Western Melanesian Lejeuneaceae, is Pócs et al. 1994). Newer papers not included in the summary of Koponen et al. (1991) are Bischler \& Piippo (1991), Piippo (1991, 1992b, 1993) and Pócs et al. (1994). Of the 708 species given for Western Melanesia by Grolle and Piippo (1984), 41 hepatic families with 90 genera and 440 species have been treated. Aneuraceae and Bazzania remain to be studied, and most of the Lejeuneaceae remain unpublished but with a large portion of the material already determined. Leucolejeunea was published by Grolle and Piippo (1990) and Pócs et al. (1994) has new records of mainly epiphyllous taxa.

\section{Results}

1. Phytogeography of Western Melanesian Lejeuneaceae

Two hundred and thirty five species reported from Western Melanesia (see Piippo 1994a) include eleven dubious taxa, i.e. those collected in New Guinea by Ledermann, whose voucher specimens were destroyed in Berlin during the Second World War. These are Archilejeunea falcifolia Steph., Ceratolejeunea ledermannii Steph., Drepanolejeunea decurviloba Steph., Leptolejeunea curvatifolia Steph., L. integristipula Steph., Otigoniolejeunea crenulata Steph., O. ledermannii Steph., Pycnolejeunea palmicola Steph., Strepsilejeunea hamatifolia Steph., S. novae-guineae Steph, and S. renistipula Steph. Because these taxa are most probably synonymous, they have been omitted from this phytogeographical paper,leaving 224 species for comparison.

If these doubtful taxa given above were included as endemic for Western Melanesia, the percentage of endemic Lejeuneaceae would be 24.15 (57 species). Now they form the second largest group with 46 species (20.54\%, Tables 2 and 3). The genera Cololejeunea and Lopholejeunea have the largest numbers of putative endemic species in Western Melanesia. About $26 \%$ of the putative endemics belong to subfamily Ptychanthoideae (Table 14).

Species currently reported only from the Malesian region (see Tables 2 and 4) are the most numerous group in species. As many as $54(24.12 \%)$ species belong to this group at this preliminary state of knowledge. About half of the Malesian endemics belong to the genera Cololejeunea, Colura, Drepanolejeunea and Lejeunea. No endemic species of Cheilolejeunea have been found in 
Malesia, and Ptychanthoideae form $22 \%$ of all the Malesian endemics (Table 14).

The category Asian-Oceanian-Australian species can be divided into subcategories (see Hyvönen 1989, Enroth 1991). Forty species, i.e. $17.86 \%$ are Asian-Oceanian (Tables 2 and 6). As many as half of the species seem to be restricted to Malesia and Oceania. Only $13 \%$ are Ptychanthoideae (Table 14) and the most species rich genera are Lejeunea with 12 species and Drepanolejeunea with 6 species. Species that extend their ranges to Australia are much fewer (22), i.e. $9.82 \%$ (Tables 2 and 7). None of these species are restricted merely to Malesia in Asia. $36 \%$ of the taxa are Ptychanthoideae (Table 14). AsianAustralian species are only 8, i.e. $3.57 \%$ (Tables 2 and 8), of which $37.5 \%$ are Ptychanthoideae (Table 14). Twenty species, i.e. $8.93 \%$ are SE Asian, and half of them belong to Cololejeunea (Tables 2 and 5). Most of the species are epiphyllous and only one belongs to Ptychanthoideae (Table 14). Paleotropical species are as many as 22 , i.e. $9.82 \%$ (Tables 2 and 10). At least 59 $\%$ of them occur as epiphylls and Cololejeunea is the richest genus. $31.8 \%$ of the group belong to Ptychanthoideae (Table 14). Pantropical taxa are 11, i.e. $4.91 \%$ (Tables 2 and 11), $45.5 \%$ of which belong to Ptychanthoideae (Table 14). Transpacific species are only 3 , i.e. $1.34 \%$ (Tables 2 and 9).

\section{Epiphyllous Lejeuneaceae of Western Melanesia}

On the Huon Peninsula 84 species of Lejeuneaceae occur on tree, shrub or fern leaves (Table 12). Many of the taxa are obligate epiphylls such as many taxa of Cololejeunea, Colura, Aphanolejeunea, Leptolejeunea, Drepanolejeunea, and Metzgeriopsis pusilla Goebel. Some Cheilolejeunea and Lejeunea species occur both on tree trunks, branches and leaves. The total number of Western Melanesian epiphyllous Lejeuneaceae is, however, higher than 84, but many species were unfortunately not encountered in the present material.

The most common epiphyllous species of Lejeuneaceae are (see Table 12):Drepanolejeunea micholitzii Steph., Lejeunea cucullata (Reinw. et al.) Nees, L. exilis (Reinw. et al.) Grolle, Caudalejeunea recurvistipula (Gott.) Schiffn., Cheilolejeunea imbricata (Nees) Hatt., Cololejeunea goebelii (Schiffn.) Schiffn., Colura conica (Sande Lac.) Grolle, and Ceratolejeunea moniliata Herz. Rather common species are also Cheilolejeunea ceylanica (Gott.) Schust. \& Kachroo, C. meyeniana (Gott. et al.) Pócs, Cololejeunea javanica (Steph.) Mizut., C. scabriflora (Gott.) Schiffn., Drepanolejeunea dentata Steph., D. spinoso-cornuta Steph., D. ternatensis (Gott.) Steph., D. thwaitesiana (Mitt.) Steph., Leptolejeunea maculata (Mitt.) Schiffn. and Tuyamaella serratistipa Hatt. Epiphyllous Ptychanthoideae are rare, with only Lopholejeunea eulopha (Tayl.) Schiffn., L. nigricans (Lindenb.) Schiffn., L. herzogiana Verd., L. dentifolia Mizut. \& Piippo, Caudalejeunea cristiloba (Steph.) Gradst., C. reniloba (Gott.) Steph., and $C$. recurvistipula were encountered in the present material.

Epiphylls are most common in rainforests, but they are common also in moss forests. The most common epiphylls listed above often endure somewhat or even heavily disturbed habitats, even though they are clearly most common in primeval rain forests. Some species occur even in gardens: Ceratolejeunea moniliata, Cololejeunea javanica, $C$. peculiaris (Herz.) Bened., C. vesicaria (Sande Lac.) Schiffn., Drepanolejeunea micholitzii, and D. ternatensis (see Hyvönen et al. 1987, Norris 1990).

On the Huon Peninsula epiphyllous Lejeuneaceae occur at altitudes of 200 $2900 \mathrm{~m}$ (Fig. 1). Many species seem to be common from 500 up to $1700 \mathrm{~m}$. They 




Fig. 1. Altitudinal ranges of Western Melanesian epiphyllous Lejeuneaceae. Vertical axis = number of species, horizontal axis $=$ altitudes in metres.

altitudes than other hepatic endemics (Piippo 1994b) or even hepatics in general (see Enroth 1991). On the Huon Peninsula no epiphylls occur above $2900 \mathrm{~m}$, an altitude previously reported as the upper limit of epiphylls in the tropics apparently because of frosts (POcs 1982, Gradstein \& Pocs 1989). According to Frahm (1990), the existence of epiphyllous liverworts in lowland rainforests, where epiphytes are rare, is a worldwide but difficult to explain phenomenon. The lower endemism figure for Lejeuneaceae can be partly explained by the more widespread nature of lowland elements in the tropics (cf. Schuster 1983). Many epiphyllous taxa are also monoicous and therefore may have better means for dispersal (cf. Gradstein \& Pocs 1989).

The percentage of Malesian endemics in Lejeuneaceae is at the present state of knowledge higher than the number of such endemics in hepatics and mosses. The reason for this is obvious when one compares the distribution of Lejeuneaceae, especially other subfamilies than the Ptychanthoideae, with the distribution of the rainforests (Pocs 1977, Richards 1984, Gradstein \& Pócs 1989, Thiers 1990, Gradstein 1991).

Asian-Oceanian-Australian Lejeuneaceae endemics are more numerous than in hepatics in general (Table 13). One possible explanation is the lack of revisional work taking into consideration taxa both from Australia, Pacific Islands and Asia. Because of the work by Gradstein and Thiers (1989) and Thiers (1987, 1988a, 1992) with the Australian hepatic flora, our knowledge of the Lejeuneaceae in Australasia is now known better than earlier. The low figure in both hepatics in general and the Lejeuneaceae for AsianAustralian taxa confirms, however, a distinctly closer affinity of hepatics from Western Melanesia with Malaysia than to Australia (cf. Piippo 1992a). This phenomenon is seen also in Marchantia, whose Western Melanesia flora, after revision, has distinct affinities with Malaysia (cf. Piippo 1992a: 30).

Due to the effective dispersal or of the relict nature of some species, typical feature for the Lejeuneaceae is the large portion of paleotropical taxa. Ptychanthoideae are most common among the pantropical, paleotropical, AsianOceanian-Australian taxa and especially among the Asian-Australian taxa (Table 14). According to Gradstein (1991), Ptychanthoideae is an ancient group of Lejeuneaceae which presumably 
are most abundant, however, at 17002200. There are almost no epiphylls over $2500 \mathrm{~m}$, and none above $2900 \mathrm{~m}$.

\section{Discussion}

The hepatic flora of SE Asia outside of Western Melanesia is still very incompletely surveyed. Therefore floristic comparisons given in the present study are only preliminary. The bryogeography of mosses, hepatics and the Lejeuneaceae are compared in the Table 13. Western Melanesian endemics are the largest group of the phytogeographical elements in mosses and hepatics in general, but not in the Lejeuneaceae. The figure of the Lejeuneaceae (20.5\%) is, however, more similar to that of mosses $(18.0 \%)$ than to that of the other hepatics $(38.2 \%)$. Endemic hepatics in general are richest between 1500 and $3500 \mathrm{~m}$ and they are most common between 2200 - $2600 \mathrm{~m}$ (Piippo 1994b). As seen from Fig. 1, the epiphyllous Lejeuneaceae, which form a large portion of all the Lejeuneaceae, are most numerous in species between 1700 and $2200 \mathrm{~m}$ and they are common also at elevations down to $300 \mathrm{~m}$. In other hepatics there are many high altitude endemics even though they are most common at rainforest altitudes. The epiphyllous Lejeuneaceae, mainly Cololejeuneoideae and Lejeuneoideae, are clearly more common at low altitudes than other hepatic endemics (Piippo 1994b) or even hepatics in general (see Enroth 1991). On the Huon Peninsula no epiphylls occur above $2900 \mathrm{~m}$, an altitude previously reported as the upper limit of epiphylls in the tropics apparently because of frosts (Pócs 1982, Gradstein \& Pócs 1989). According to Frahm (1990), the existence of epiphyllous liverworts in lowland rainforests, where epiphytes are rare, is a worldwide but difficult to explain phenomenon. The lower endemism figure for Lejeuneaceae can be partly explained by the more widespread nature of lowland elements in the tropics (cf. Schuster 1983). Many epiphyllous taxa are also monoicous and therefore may have better means for dispersal (cf. Gradstein \& Pócs 1989).

The percentage of Malesian endemics in Lejeuneaceae is at the present state of knowledge higher than the number of such endemics in hepatics and mosses. The reason for this is obvious when one compares the distribution of Lejeuneaceae, especially other subfamilies than the Ptychanthoideae, with the distribution of the rainforests (Pócs 1977, Richards 1984, Gradstein \& Pócs 1989, Thiers 1990, Gradstein 1991).

Asian-Oceanian-Australian Lejeuneaceae endemics are more numerous than in hepatics in general (Table 13). One possible explanation is the lack of revisional work taking into consideration taxa both from Australia, Pacific Islands and Asia. Because of the work by Gradstein and Thiers (1989) and Thiers (1987, 1988a, 1992) with the Australian hepatic flora, our knowledge of the Lejeuneaceae in Australasia is now known better than earlier. The low figure in both hepatics in general and the Lejeuneaceae for AsianAustralian taxa confirms, however, a distinctly closer affinity of hepatics from Western Melanesia with Malaysia than to Australia (cf. Piippo 1992a). This phenomenon is seen also in Marchantia, whose Western Melanesia flora, after revision, has distinct affinities with Malaysia (cf. Piippo 1992a: 30).

Due to the effective dispersal or of the relict nature of some species, typical feature for the Lejeuneaceae is the large portion of paleotropical taxa. Ptychanthoideae are most common among the pantropical, paleotropical, Asian-Oceanian-Australian taxa and especially among the Asian-Australian taxa (Table 14). According to Gradstein (1991), Ptychanthoideae is an ancient group of Lejeuneaceae which presumably existed already in the Mesozoic before the break-up of Laurasia and 
Gondwanaland.

\section{Acknowledgements}

I wish to thank Professors Timo Koponen and Daniel H.

Norris for their comments on the text.

\section{References}

Bischler, H. 1968. Monographie du genre Rhaphidolejeunea Herzog (1). Rev. Bryol. Lichénol. 36: 56-104. \& S. Piippo 1991. Bryophyte flora of the Huon Peninsula, Papua New Guinea. L. Marchantia (Marchantiaceae, Hepaticae). Ann. Bot. Fennici 28: 277301.

Bizot, M. \& T. Pócs. 1974. East African bryophytes I. Acta Acad. Paedag. Agr. II, 12: 383-449.

\& . 1979. East African bryophytes II. Acta Bot. Acad. Scient. Hung. 25: 223-261.

Bonner, C. E. B. 1963. Index Hepaticarum.III. Barbilophozia to Ceranthus. 321-636 pp. Weinheim.

1978. Index Hepaticarum. IX. Jungermanniopsis to Lejeunites. 405-745 pp. Vaduz.

Enroth, J. 1991. On the phytogeography of Western Melanesian Hepaticae. A literature review. J. Hattori Bot. Lab. 70: $1-42$.

Frahm, J.-P. 1990. The altitudinal zonation of bryophytes on Mt. Kinabalu. Nova Hedwigia 51: 133-149.

Gradstein, S. R. 1975. A taxonomic monograph of the genus Acrolejeunea (Hepaticae) with an arrangement of the genera of Ptychanthoideae. Bryophytorum Bibliotheca 4: 1-162, 26 pls.

1985. A revision of the genus Stictolejeunea (Spruce) Schiffn. Nova Hedwigia Beih. 80: 195-220.

. 1991. Diversity and distribution of Asian Lejeuneaceae subfamily Ptychanthoideae. Tropical Bryology 4: 1-16.

— \& G. M. C. Buskes. 1985. A revision of neotropical Archilejeunea (Spruce) Schiffn. Nova Hedwigia Beih. 80: 89-112.

. \& W. H. A. Hekking. 1979. A catalogue of the Hepaticae of Colombia. J. Hattori Bot. Lab. 45: 93144.

— \& T. Pócs. 1989. Bryophytes. In Lieth, H. \& M. J. A. Werger (eds.), Tropical rainforest ecosystems: 311325. Elsevier Sci. Publ.; Amsterdam.

\& L. Terken. 1981. Studies on Lejeuneaceae subfam. Ptychanthoideae VI. A revision of Schiffneriolejeu- nea sect. Saccatae from Asia. Occas. Pap. Farlow Herb. 16: 71-81.

Grolle, R. 1966. Über Diplasiolejeunea in Asien. Feddes Repert. 73: 78-89.

- 1967. Lebermoose aus Neuguinea. 6. Dritte Fundliste. J. Hattori Bot. Lab. 30: 113-118.

. 1968. Einige ostmalesische Lebermoose. Nova Hedwigia 16: 147-159.

1982. Übersicht der Lejeuneaceae in Tasmanien. Wiss. Zeitschr. Friedr. Sch. Univ. 31: 207-227.

1985. Zur Kenntnis der Lebermoosgattung Otolejeunea. Haussknechtia 2: 45-56.

. 1986. Miscellanea hepaticologica 241-250. J. Hattori Bot. Lab. 61: 249-255.

1987. Miscellanea hepaticologica 251-260. J. Hattori Bot. Lab. 63: 437-443.

.1988. Miscellanea hepaticologica 261-270. J. Hattori Bot. Lab. 65: 403-410.

\& Piippo, S. 1984. Annotated catalogue of Western Melanesian bryophytes. I. Hepaticae and Anthocerotae. Acta Bot. Fennica 125: 1-86.

\& - 1990. Bryophyte flora of the Huon Peninsula, Papua New Guinea. XXXVII. Leucolejeunea (Lejeuneaceae, Hepaticae). Ann. Bot. Fennici 27: 119-129.

Hamlin, B. G. 1972. Hepaticae of New Zealand, parts I and II. Index of binomials and preliminary checklist. Rec. Dom. Mus. 7: 243-366.

Herzog, T. 1951. Hepaticae Standleyanae Costaricensis et Hondurensis II. Rev. Bryol. Lichénol. 20: 126-175.

Hyvönen, J. 1989. On the bryogeography of Western Melanesia. J. Hattori Bot. Lab. 66: 231-254.

Hyvönen, J., Koponen, T. \& Norris, D. H. 1987. Human influence on the mossflora of tropical rainforest in Papua New Guinea. Symp. Biol. Hung. 35: 639-648.

Jovet-Ast, S. 1953. Le genre Colura. Hépatiques. Lejeuneaceae, Diplasiae. Rev. Bryol. Lichénol. 22: 206-312. 1960. Muscinées du Mexique récoltées par Roger Heim en 1956 et 1959. Rev. Bryol. Lichénol. 29: 3043.

1961. Colura du Sud-Vietnam. Récoltes de Pierre Tixier. Rev. Bryol. Lichénol. 30: 5-12.

Koponen, T. \& D. H. Norris. 1983. Bryophyte flora of the Huon Peninsula, Papua New Guinea. I. Study area and its bryological exploration. Ann. Bot. Fennici 20: 1529.

, Piippo, S. \& D. H. Norris. 1991. Bryophyte flora of the Huon Peninsula, Papua New Guinea. XLVII Generic index to parts I-XLVI. In T. Koponen (ed.), Bryophyte flora of the Huon Peninsula, Papua New 
Guinea XXXIX-XLVII: 107-111. Acta Bot. Fennica 143.

Long, D. \& R. Grolle. 1990. Hepaticae of Bhutan II. J. Hattori Bot. Lab. 68: 381-440.

Luo, J.-X. 1990. A synopsis of Chinese epiphyllous liverworts. Tropical Bryology 2: 161-166.

Menzel, M. 1988. Annotated catalogue of the Hepaticae and Anthocerotae of Borneo. J. Hattori Bot. Lab. 65: 145206.

Miller, H. A., Whittier, H. O. \& Whittier, B. A. 1983. Prodromus Florae Hepaticarum Polynesiae with a key to genera. Bryophytorum Bibliotheca 25: 1-423.

Mizutani, M. 1961. A revision of Japanese Lejeuneaceae. J. Hattori Bot. Lab. 24: 115-302.

1963. On some Indian species of the family Lejeuneaceae described by W. Mitten. J. Hattori Bot. Lab. 26: 171-184.

1964. Studies of little known Asiatic species of Hepaticae in the Stephani herbarium. 1. On some little known Asiatic species of the family Lejeuneaceae. J. Hattori Bot. Lab. 27: 139-148.

- 1965. Studies of little known Asiatic species of Hepaticae in the Stephani herbarium. 2. On some little known Southeast Asiatic species of the genus Cololejeunea. J. Hattori Bot. Lab. 28: 107-121.

1967. Studies of little known Asiatic species of Hepaticae in the Stephani herbarium. 3. On some little known species of Cheilolejeunea, Euosmolejeunea and Pycnolejeunea. J. Hattori Bot. Lab. 30: 171-180.

1968. Studies of little known Asiatic species of Hepaticae in the Stephani herbarium. 4. Phaeolejeunea, a new genus of Lejeuneaceae. J. Hattori Bot. Lab. 31: 130-134.

1970. Lejeuneaceae, subfamilies Lejeuneoideae and Cololejeuneoideae from Sabah (North Borneo). J. Hattori Bot. Lab. 33: 225-265.

- 1972a. Studies of little known Asiatic species of Hepaticae in the Stephani herbarium. 8. Some little known species of the Subfamily Lejeuneoideae of the Lejeuneaceae. J. Hattori Bot. Lab. 36: 157-162.

- 1972b. Studies of little known Asiatic species of Hepaticae in the Stephani herbarium. 7. Some little known species of the subfamily Lejeuneoideae of the Lejeuneaceae. J. Hattori Bot. Lab. 35: 399-411.

1973. The genus Harpalejeunea from Sabah (North Borneo). J. Hattori Bot. Lab. 37: 191-203.

1975. Epiphyllous species of Lejeuneaceae from the Philippines. J. Hattori Bot. Lab. 39: 255-262.

1976. Studies of little known Asiatic species of Hepaticae in the Stephani herbarium. 9. Some little- known species of family Lejeuneaceae. J. Hattori Bot. Lab. 40: 441-446.

1977. Lejeuneaceae from the Philippines. J. Hattori Bot. Lab. 43: 127-136.

1978. Lejeuneaceae from Ishigaki and Iriomote Islands of Ryukyu Archipelago. J. Hattori Bot. Lab. 44: 121-136.

1979a. Notes on the Lejeuneaceae. 1. Some Asiatic species of the genus Lopholejeunea. J. Hattori Bot. Lab. 45: 375-387.

- 1979b. Notes on the Lejeuneaceae. 2. Some peculiar Asiatic species in the Rijksherbarium, Leiden. J. Hattori Bot. Lab. 46: 357-372.

1980. Notes on the Lejeuneaceae. 3. Some Asiatic species of the genus Cheilolejeunea. J. Hattori Bot. Lab. 47: 319-331.

-1981. Notes on the Lejeuneaceae. 5. Some Asiatic species of the genus Ceratolejeunea. J. Hattori Bot. Lab. 49: 305-318.

.1982. Notes on the Lejeuneaceae. 6. Japanese species of the genus Cheilolejeunea. J. Hattori Bot. Lab. 51: 151-173.

. 1984a. Notes on the Lejeuneaceae. 8. Japanese species of the subgenus Taeniolejeunea of the genus Cololejeunea. J. Hattori Bot. Lab. 57: 153-170.

- 1984b. Notes on the Lejeuneaceae. 9. Cololejeunea lanciloba and its related species in Japan. J. Hattori Bot. Lab. 57: 427-442.

-1984c. Notes on Lejeuneaceae. 7. Calatholejeumnea paradoxa, C. lamii (sp. nov.) and Plagiolejeunea zantenii (gen. et sp. nov.). J. Hattori Bot. Lab. 56: 331-338.

. 1985. Notes on the Lejeuneaceae. 10. Some Asiatic species of the genus Lopholejeunea. J. Hattori Bot. Lab. 59: 469-480.

. 1986a. Lejeuneaceae from Seram Island, Indonesia. J. Hattori Bot. Lab. 61: 299-308.

- 1986b. Notes on the Lejeuneaceae. 12. Mastigolejeunea humilis and its related species from Asia. J. Hattori Bot. Lab. 61: 281-297.

- 1987. Notes on the Lejeuneaceae. 13. Some Asiatic species of the genus Thysananthus. J. Hattori Bot. Lab. 63: 411-419.

.1988. Notes on the Lejeuneaceae. 14. Asiatic species of the genus Caudalejeunea. J. Hattori Bot.Lab. 64:389399.

- 1989. Notes on the Lejeuneaceae. 15. Three species of the genus Trocholejeunea. J. Hattori Bot. Lab. 66: 271-281.

.1990. Notes on the Lejeuneaceae. 16. Drepanolejeunea thwaitesiana and its related species from Asia. J. 
Hattori Bot. Lab. 68: 367-380.

- \& S. Piippo. 1986. Some species of Lejeuneaceae from New Guinea. J. Hattori Bot. Lab. 61: 477-485.

Norris, D. H. 1990. Bryophytes in perennially moist forests of Papua New Guinea: ecological orientation and predictions of disturbance effects. Bot. J. Linn. Soc. 104: 281-291.

Onraedt, M. 1991. Bryophytes des Iles Philippines. 1. Le genre Leptolejeunea (Spruce) Steph. J. Hattori Bot. Lab. 70: 157-166.

Piippo, S. 1986. A monograph of the genera Lepidolejeunea and Luteolejeunea (Lejeuneaceae, Hepaticae). Acta Bot. Fennica 132: 1-69.

1990. Annotated catalogue of Chinese Hepaticae and Anthocerotae. J. Hattori Bot. Lab. 68: 1-192.

- 1991. Bryophyte flora of the Huon Peninsula, Papua New Guinea. XLIX. Targionia (Targioniaceae, Hepaticae). Ann. Bot. Fennici 28: 273-276.

1992a. On the phytogeographical affinities of temperate and tropical Asiatic and Australasiatic hepatics. J. Hattori Bot. Lab. 71: 1-35.

1992b. Bryophyte flora of the Huon Peninsula, Papua New Guinea. LI. Additions and corrections to the Geocalycaceae (Hepaticae). Ann. Bot. Fennici 29: 243-248.

-1992c. About the distribution and diversity of Chinese hepatic flora. Bryobrothera 1: 93-97.

-1993. Bryophyte flora of the Huon Peninsula, Papua New Guinea. LIV. Anthocerotophyta. In T. Koponen (ed.), Bryophyte flora of the Huon Peninsula, Papua New Guinea LII-LIV: 27-51. Acta Bot. Fennica 148. 1994a. On the present state of study of Western Melanesian Lejeuneaceae. J. Hattori Bot. Lab. (in press).

1994b. Phytogeography and habitat ecology of Western Melanesian endemic Hepaticae. J. Hattori Bot. Lab. (in press).

_., T. Koponen \& D. H. Norris. 1987. Endemism of the bryophyte flora in New Guinea. Symp. Biol. Hung.35: 361-372.

Pócs, T. 1977. Epiphyllous communities and their distribution in East Africa. Bryoph. Biblioth. 13: 681-713.

1982. Tropical forest bryophytes. In A. E. J. Smith (ed.), Bryophyte ecology: 59-104. Chapman and Hall. London, New York.

1984. Present knowledge on Aphanolejeunea Evans. J. Hattori Bot. Lab. 55: 307-313.

, M. Mizutani, \& S. Piippo 1994. Bryophyte flora of the Huon Peninsula, Papua New Guinea. 000. Preliminary contributions on Lejeuneaceae (Hepaticae) 1. 
Acta Bot. Fennica (in press).

Richards, P. W. 1984. The ecology of tropical forest bryophytes. In R. M. Schuster (ed.), New Manual of Bryology 2: 12331270. Hattori Bot. Lab., Nichinan.

Schuster, R. M. 1980. The Hepaticae and Anthocerotae of North America. 1.i-xviii, 1334 pp. Columbia Univ. Press. New York.

- 1983. Phytogeography of the bryophytes. In R. M. Schuster (ed.), New Manual of Bryology 1: 463-626. Hattori Bot. Lab.; Nichinan.

Scott, G. A M. \& J. A. Bradshaw. 1986. Australian liverworts (Hepaticae): annotated list of binomials and check-list of published species with bibliography. Brunonia 8: 1-171.

Tan, B. C. \& J. J. Engel. 1986. An annotated checklist of Philippine Hepaticae. J. Hattori Bot. Lab. 60: 283-355.

Thiers, B. M. 1987. A preliminary account of Colura (Hepaticae, Lejeuneaceae) in Australia. Brittonia 39: 175-179.

- 1988a. The Australian species of Cololejeunea. Nova Hedwigia Beih. 90: 113-146.

1990. An overview of the Lejeuneaceae in Australia. Trop. Bryol.2: 273-283.

1992. A re-evaluation of Cheilolejeunea subgenus Xenolejeunea. Tropical Bryology 5: 10-21.

\& S. R. Gradstein 1989. Lejeuneaceae (Hepaticae) of Australia. I. Subfamily Ptychanthoideae. Mem. New York Bot. Gard. 52: 1-82.

Tixier, P. 1980. Contribution to the bryological knowledge of Malaysia. III. Cameroon Highlands, mosses and epiphyllous liverworts. Nova Hedwigia 32: 377-392.

- 1985. Contribution à la connaissance des Cololejeunoideae. Bryophytorum Bibliotheca 27: 1-439.

. 1988. Le domaine lémuro-australasien. Intéret

biogéographique de deux espèces nouvelles. Nova Hedwigia 46: 373-383.

TABLE 1. Comparison of Western Melanesian Lejeuneaceae flora with other regions (partly according to Thiers 1990)

$\underline{\text { Region }}$

Western Melanesia

Borneo

Columbia

China

Philippines

Australia

Costa Rica

East Africa

Japan
Source

Pócs et al. 1994

Menzel 1988

Gradstein \&

Hekking 1979

Piippo 1990, 1992

Tan \& Engel 1986

Thiers 1990

Herzog 1951

Bizot \& Pócs

1974, 1979

Mizutani 1961
No. of spec. 
North America

Schuster 1980

New Zealand

Hamlin 1972

TABLE 2. Bryogeography of Western Melanesian Lejeuneaceae

No. of spec.

$\%$

1. Endemics of Western Melanesia 46

20.54

2. Endemics of Malesian region 54

24.12

3. SE Asian species

20

4.1 Asian-Oceanian

40

17.86

4.2 Asian-Oceanian-Australian 22

9.82

4.3 Asian-Australian

8

5. Transpacific

3

1.34

6. Paleotropical

22

9.82

7. Pantropical

11

4.91

TABLE 3. Endemic taxa of Lejeuneaceae

63

45

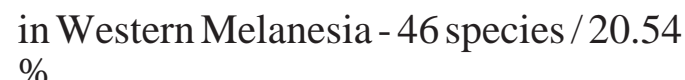

Acrolejeunea pycnoclada (Tayl.) Schiffn. subsp. latistipula Gradst.

Aphanolejeunea ciliata Pócs

A. morobensis Pócs

Calatholejeunea lamii Mizut.

Cololejeunea angustibracteata Schiffn.

C. angustiflora (Steph.) Mizut.

C. cardiocalyx (Schiffn.) Schiffn. \& Steph.

C. floccosa (Lehm. \& Lindenb.) Schiffn. var. auriculata Tix.

C. koponenii Pócs

C. quadridentata (Hatt.) Grolle

Colura pallida Steph.

C. schusteri Grolle

Dicranolejeunea inoueana Mizut. \& Piippo

Drepanolejeunea lyrata Grolle

D. tuyamae Hatt.

D. yulensis Steph.

Harpalejeunea pinaundensis Grolle Lejeunea lancistipula (Steph.) H. A. Miller et al.

L. parallela Schiffn.

Leptolejeunea minima Herz.

L. minutistipula Steph. ex Herz.

Leucolejeunea gradsteinii Grolle \& Piippo

L. loriana (Steph.) Mizut.

L. suprema Grolle \& Piippo

Lopholejeunea acutifolia Mizut. \& Piippo

L. dentifolia Mizut. \& Piippo

L. evansiana Verd.

L. latilobula Verd.

L. pullei Verd.

Microlejeunea erectifolia Spruce

M. koponensis Pócs

Otolejeunea streimannii Grolle

O. zantenii Grolle

Phaeolejeunea inermis (Steph.) Mizut.

Pycnolejeunea fitzgeraldii Steph.

P. grossiloba Steph.

Rhaphidolejeunea bischlerae Grolle

Siphonolejeunea schiffneri (Steph. ex Schiffn.) Herz.

Spruceanthus macrostipulus (Steph.) 
Gradst.

S. pluriplicatus (Steph.) Gradst.

Stenolejeunea morobensis Grolle

Taxilejeunea giulianettii Steph.

T. nymanii Steph.

T. stephanii Eifrig

Thysananthus appendiculatus (Steph.)

Steph.

T. mollis Steph.

Trachylejeunea englishii Steph.

TABLE 4. Endemic species of Lejeuneaceae of Malesian region - 54 species / $24.12 \%$

Acrolejeunea arcuata (Nees) Grolle \& Gradst.

A. tjibodensis (Verd.) Grolle \& Gradst.

Calatholejeunea paradoxa (Schiffn.)

Goebel

Cheilolejeunea gigantea (Steph.) Schust.

\& Kachroo

C. lindenbergii (Gott.) Mizut.

C. occlusa (Herz.) Kodama \& Kitag.

C. paroica Mizut.

Cololejeunea angulata (Steph.) Mizut.

C. dozyana (Sande Lac.) Schiffn.

C. javanica (Steph.) Mizut.

C. pseudostipulata (Schiffn.) Bened.

C. stephanii Bened.

C. vesicaria (Sande Lac.) Schiffn.

Colura clementis Grolle

C. crenulata Grolle

C. junghuhniana (Steph.) Steph.

C. karstenii Goebel

C. speciosa Jov.-Ast

Dicranolejeunea javanica Steph.

Diplasiolejeunea jovet-astiae Grolle

D. patelligera Herz.

Drepanolejeunea blumii (Steph.) Schiffn.

D. dentata Steph.

D. fissicornua Steph.

D. levicornua Steph.

D. longicornua (Herz.) Mizut.

D. nymanii Steph.

D. spinoso-cornuta Steph.

D. tricornua Herz.

Harpalejeunea constricta Grolle
Lejeunea dimorpha Kodama

L. fleischeri (Steph.) Mizut.

L. herzogii Mizut.

L. kinabalensis Mizut.

L. microstipula Steph.

L. mizutanii Grolle

L. molkenboeriana Sande Lac.

L. nymanii Steph.

Leptolejeunea dentistipula Steph.

L. serrulata Herz.

Lopholejeunea herzogiana Verd.

L. recurvata Mizut.

L. wiltensii Steph.

Mastigolejeunea recondita (Steph.)

Mizut.

M. truncata Mizut.

Otolejeunea semperiana Grolle

Pictolejeunea mizutanii Grolle

Pycnolejeunea cavistipula (Steph.)

Mizut.

Rhaphidolejeunea longicruris (Steph.)

Herz.

Schiffneriolejeunea nymanii (Steph.)

Gradst. \& Terken

S. omphalanthoides Verd.

Stenolejeunea thallophora (Eifrig)

Schust.

Thysananthus minor Verd.

Trocholejeunea crassicaulis (Steph.)

Mizut.

Tuyamaella serratistipula Hatt.

TABLE 5. SE Asian species of Lejeuneaceae - 20 species / $8.93 \%$

Acrolejeunea fertilis (Reinw. et al.) Schiffn.

Aphanolejeunea angustiloba Horik.

A. grossepapillosa Horik.

Cololejeunea desciscens Steph.

C. equialbi P. Tix.

C. falcatoides Bened.

C. hirta Steph.

C. leonidens Bened.

C. madothecoides (Steph.) Bened.

C. peculiaris (Herz.) Bened.

C. pseudofloccosa (Horik.) Bened.

C. schmidtii Steph. 
C. triapiculata (Herz.) Tix.

Colura meijeri Jov.-Ast

Drepanolejeunea thwaitesiana (Mitt.)

Steph.

Lejeunea catanduana (Steph.) H. A.

Miller et al.

L. eifrigii Mizut.

L. leratii (Steph.) Mizut.

Pycnolejeunea grandiocellata Steph.

Tuyamaella angulistipa (Steph.) Schust. \& Kachroo

TABLE 6. Asian-Oceanian species of Lejeuneaceae (if only in Malesia *)

- 40 species / $17.86 \%$

Caudalejeunea recurvistipula (Gott.) Schiffn.

Ceratolejeunea moniliata Herz.

* Cheilolejeunea cookiensis (Steph.) Schust. \& Kachroo

* C. germanii (Besch. \& Spruce) Grolle

C. mariana (Gott.) Thiers \& Gradst.

Cololejeunea cordiflora Steph.

C. hasskarliana (Lehm. \& Lindenb.)

Steph.

C. longifolia (Mitt.) Bened.

Colura corynephora (Nees et al.) Trev.

* C. imperfecta Steph.

* C. pluridentata Jov.-Ast

Drepanolejeunea dactylophora (Gott. et al.) Schiffn.

* D. intermedia Zwickel

D. pentadactyla (Mont.) Steph.

* D. serricalyx Herz.

D. tenera Goebel

D. teysmannii Gott. et al.

Lejeunea albescens (Steph.) Mizut.

* L. asperula (Steph. Mizut.

* L. crenulata (Schiffn.) Steph.

* L. cuculliflora (Steph.) Mizut.

* L. exilis (Reinw. et al.) Grolle

* L. gracilis Steph.

* L. lumbricoides (Nees) Nees

L. micholitzii Mizut.

* L. microloba Tayl.
* L. parvisaccata (Steph.) Steph.

* L. patersonii (Steph.) Steph.

L. umbilicata (Nees) Gott. et al.

* Lepidolejeunea graeffei (Jack \& Steph.)

Schust.

* L. integristipula (Jack \& Steph.) Schust.

Leptolejeunea amphiophthalmaZwickel

* L. lancifolia (Mitt.) Steph.

L. subacuta Steph. ex Evans

Mastigolejeunea repleta (Tayl.) Steph.

Metzgeriopsis pusilla Goebel

* Microlejeunea atsuana Steph.

Phaeolejeunea latistipula (Schiffn.)

Mizut.

* Thysananthus comosus Lindenb.

T. convolutus Lindenb.

TABLE 7. Asian-Oceanian-Australian species of Lejeuneaceae - 22 species/ $9.82 \%$

Archilejeunea polymorpha (Sande Lac.)

B. Thiers \& Gradst.

Caudalejeunea cristiloba (Steph.) Gradst.

C. reniloba (Gott.) Steph.

Cheilolejeunea falsinervis (Sande Lac.)

Kachroo \& Schust.

C. imbricata (Nees) Hatt.

C. meyeniana (Gott. et al.) Pócs

Cololejeunea goebelii (Gott. ex Schiffn.)

Schiffn.

C. wightii Steph.

Colura acroloba (Mont. ex Steph.) Jov.-

Ast

C. ari (Steph.) Steph.

C. conica (Sande Lac.) Goebel

Drepanolejeunea ternatensis (Gott.)

Steph.

D. vesiculosa (Mitt.) Steph.

Harpalejeunea filicuspis (Steph.) Mizut.

Lejeunea discreta Lindenb.

L. sordida (Nees) Nees

Leptolejeunea maculata (Mitt.) Schiffn.

Mastigolejeunea ligulata (Lehm. \& Lindenb.) Schiffn.

$M$. virens (Aongstr.) Steph.

Schiffneriolejeunea cumingiana (Mont.) 
Gradst.

S. tumida (Nees) Gradst.

Thysananthus fruticosus (Lindenb. \& Gott.) Schiffn.

TABLE 8. Asian-Australian species of Lejeuneaceae - 8 species $/ 3.57 \%$

Archilejeunea planiuscula (Mitt.) Steph. Caudalejeunea lessonii Steph.

Cheilolejeunea incisa (Gott.) Schust. \&

Kachroo

C. longidens (Steph.) Kachroo \& Schust. C. vittata (Steph. ex Hoffm.) Schust. \& Kachroo

Drepanolejeunea obliqua Steph.

Lejeunea armitii (Steph.) Steph.

Mastigolejeunea undulata Gradst. \& Grolle

TABLE 9. Transpacific species of Lejeuneaceae - 3 species / $1.34 \%$

Cheilolejeunea trifaria (Reinw. et al.) Mizut.

Cololejeunea scabriflora (Gott.) Schiffn.

Diplasiolejeunea cavifolia Steph.

TABLE 10. Paleotropical species of Lejeuneaceae $(*=$ not in Australia, $=$ not in India, $Ð=$ not in Africa) - 22 species / $9.82 \%$

Acrolejeunea aulacophora (Mont.) Steph.

* A. pycnoclada (Tayl.) Schiffn.

* Ceratolejeunea belangeriana (Gott.) Steph.

Cheilolejeunea ceylanica (Gott.) Schust.

\& Kachroo

C. intertexta (Lindenb.) Steph.

* C. appressa (Evans) Bened.

C. floccosa (Lehm. \& Lindenb.) Schiffn.

C. inflectens (Mitt.) Bened.

$\bar{Ð}$ C. lanciloba Steph.

C. peraffinis (Schiffn.) Schiffn.
*_Colura superba (Mont.) Steph.

* Drepanolejeunea angustifolia (Mitt.)

Grolle

_D. micholitzii Steph.

*_Lejeunea alata Gott.

Lepidolejeunea bidentula (Steph.) Schust.

* Leptolejeunea epiphylla (Mitt.) Steph.

*_L. vitrea (Nees) Schiffn.

* Lopholejeunea applanata (Reinw. et al.) Schiffn.

* L. javanica (Nees) Schiffn.

Ptychanthus striatus (Lehm. \& Lindenb.)

Nees

Thysananthus retusus (Reinw. et al.) B.

Thiers \& Gradst.

T. spathulistipus (Reinw. et al.) Lindenb.

TABLE 11. Pantropical species of Lejeuneaceae $(*=$ not in Australia, $Đ=$ not in Africa) - 11 species / $4.91 \%$

* Colura tenuicornis (Evans) Steph.

Lejeunea caespitosa Lindenb.

L. cucullata (Reinw. et al.) Nees

L. flava (Sw.) Nees

Đ Leptolejeunea elliptica (Lehm. \& Lindenb.) Schiffn.

Leucolejeunea xanthocarpa (Lehm. \& Lindenb.) Evans

Lopholejeunea eulopha (Tayl.) Schiffn.

L. nigricans (Lindenb.) Steph.

L. subfusca (Nees) Steph.

Mastigolejeunea auriculata (Wils.)

Schiffn.

Stictolejeunea balfourii (Mitt.) E. W. Jones

TABLE 12. Epiphyllous Lejeuneaceae on the

Huon Peninsula. No. $=$ number of collections

No.

Aphanolejeunea ciliata 1

A. angustiloba

A. grossepapillosa 
1

A. morobensis 2

Caudalejeunea recurvistipula

C. reniloba 3

Ceratolejeunea belangeriana 3

C. moniliata

Cheilolejeunea ceylanica $\quad 15$

C. falsinervis 2

C. imbricata

28

C. lindenbergii

C. meyeniana

C. occlusa

C. trifaria

C. vittata

Cololejeunea ciliata

C. cordiflora

C. equialbi

C. goebelii

C. hasskarliana

C. hirta

C. javanica

C. koponenii

C. lanciloba

C. peculiaris

C. peraffinis

C. pseudofloccosa

3

1

8

C. scabriflora

C. schmidtii

C. vesicaria

Colura acroloba

C. ari

C. conica

C. imperfecta

C. meijeri

C. ornata

Drepanolejeunea dactylophora

D. dentata

D. fissicornua

D. intermedia

D. laevicornua

D. longicornua

D. micholitzii

D. serricalyx

D. spinoso-cornuta

D. tenera

D. ternatensis

D. teysmannii

D. thwaitesiana

D. vesiculosa

Harpalejeunea constricta

H. filicuspis

Lejeunea alata

L. albescens

L. catanduana

13

L. cucullata

L. dimorpha

L. discreta

L. exilis

L. flava

L. herzogii

2

L. kinabalensis

L. leratii

L. lumbricoides 
TABLE 14. The proportion of subfamily Ptychanthoideae in Western Melanesia. a $=$ proportion of ptychanthoid species of the phytogeographical element in question $(\%), b=$ proportion of ptychanthoid species of the whole Lejeuneaceae flora (226). - For details, see the text.

a b

Endemics of Western Melanesia

$26.1 \quad 5.4$

Endemics of Malesian region

22.2

5.4

SE Asian species

$\begin{array}{ll}5.0 & 0.5\end{array}$

Asian-Oceanian

12.5

2.2

Asian-Oceanian-Australian

36.4

Asian-Australian

37.5

1.3

Transpacific

Paleotropical

31.8

3.1

Pantropical

45.5

2.2 